\title{
Handling of Clinical Tissue Specimens for Molecular Profiling Studies
}

\author{
Isabel M. Leiva ${ }^{1,2}$, Michael R. Emmert-Buck ${ }^{1}$ \\ and John W. Gillespie ${ }^{1,3}$ \\ ${ }^{1}$ Pathogenetics Unit, Laboratory of Pathology and Urologic \\ Oncology Branch, National Cancer Institute, National \\ Institutes of Health, Bethesda, MD 20892, USA \\ ${ }^{2}$ Pontificia Universidad Católica de Chile, Marcoleta 345 \\ Piso 4, Santiago, Chile \\ ${ }^{3}$ Science Applications International Corporation, National \\ Cancer Institute, National Institutes of Health, Bethesda, \\ MD 20892, USA
}

\begin{abstract}
The relationship between gene expression profiles and cellular phenotypes is an important aspect of functional genomics. Clinical tissue specimens will play a vital role in this effort. The usefulness of tissue for molecular profiling is significantly influenced by the manner of specimen handling. Crucial components of this process include the optimization of the methods of tissue fixation and embedding, not only to obtain excellent histological detail, but also to promote the elucidation of the gene and protein expression profiles. In this article, we describe handling of clinical specimens using whole-mount prostate as an example, the use of new high-throughput techniques that allow molecular profiling analysis and the use of a webbased 3-dimensional model to combine these data to make it available to clinicians and the research community. Complete protocols and additional discussion are available on the website, http://cgapmf.nih.gov.
\end{abstract}

\section{Introduction}

The field of molecular pathology has been impacted recently by the expanding base of genetic information from the Human Genome Project, and by the development of high-throughput technologies to obtain gene and protein expression profiles. These developments have allowed for a tremendous increase in the rate of data production (Schena et al., 1995; DeRisi et al., 1996; Anderson et al., 1998; Lipshutz et al., 1999; Emmert-Buck et al., 2000) making a comprehensive study of disease processes at the molecular level feasible.

Several experimental systems for molecular profiling are available, including animal models, human cells in vitro (Zhang et al., 1997; Celis et al., 1999), and ex vivo specimens. The molecular profiles of cells in vitro may not

*For correspondence. Email ileiva@med.puc.cl; Tel. (562) 633-1541; Fax. (562) 633-5255. always be reflective of the molecular profiling seen in vivo (Ornstein et al., 2000) since there may be artifacts in gene and protein expression induced by the culture conditions. Since ex vivo samples analyzed directly from patients most closely represent conditions in vivo, molecular profiles derived from them likely will give pertinent information on the disease processes, including pathogenesis and also potentially clinically important information such as diagnostic, prognostic markers and therapeutic targets.

There are several different types of samples that can be obtained from patients, including blood, body fluids, cells, and whole tissue. Since many disease processes have their origin within tissues, these represent an important source of material necessary to study pathogenesis. However, there are considerations in the handling and processing of tissue that should be considered when one is undertaking research on clinical samples. Detailed information regarding these steps are available in the section of prostate molecular profiling at National Cancer Institute on the website http://cgapmf.nih.gov as part of the Molecular Profile Initiative at the National Cancer Institute.

Snap-freezing, or fixation and embedding are the two different ways in which tissue is typically processed. Figure 1 shows the steps of tissue handling for both freezing, as well as fixation and embedding. Traditionally, tissue which is to be used for molecular analysis is frozen, whereas tissue which is to be examined histologically is fixed and embedded. Since the diagnosis of many diseases is usually performed based on histologic examination, fixation and embedding methods for clinical tissue specimens in pathology departments do not generally prioritize preservation of DNA, RNA, and proteins. The focus has been to achieve excellent histology. Therefore, standard surgical pathology procedures are inadequate for use with high-throughput molecular technologies (Ben-Ezra et al., 1991; Klimecki et al., 1994). Traditionally, optimal molecular preservation in tissue has been achieved through snapfreezing. The disadvantages of this method are poor histology (Fend et al., 1999; Gillespie et al., 2000) as well as inconvenient storage and handling. In the future, it is important that tissue fixation and embedding methods should integrate both excellent histology and optimal molecular preservation. In this way, the information obtained not only from the histology, but also from molecular analysis will provide insight into molecular etiology of disease processes. There are many steps in fixation and tissue processing in which different physical and chemical conditions can be varied to optimize both histology and molecular preservation (Figure 1). Ultimately, it is critical that a "universal protocol" be developed for fixation and embedding which would not only retain excellent histology and allow convenient storage and handling, but would also ideally preserve biomolecules. 


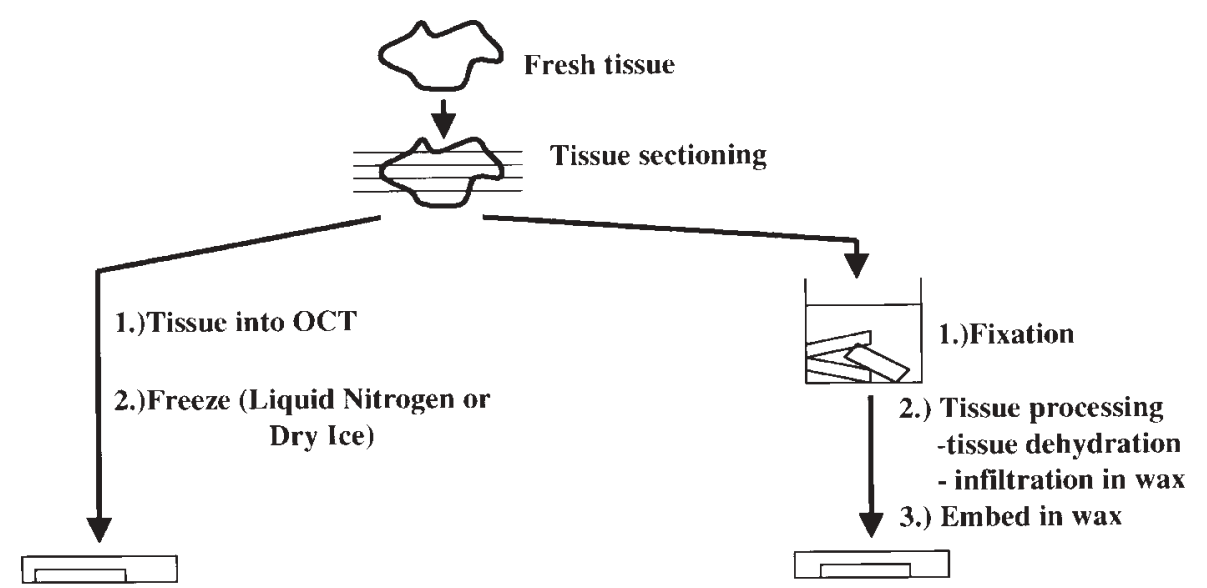

Tissue block

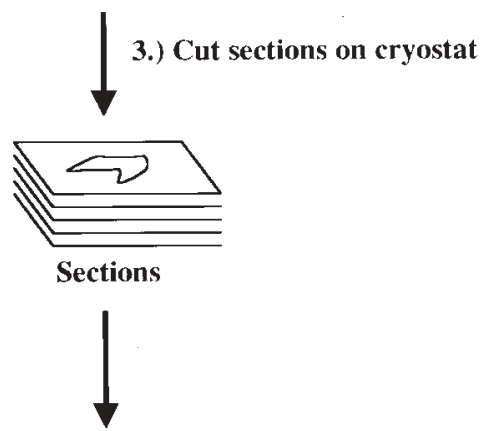

H\&E stain, IHC, LCM, LES, etc.
Tissue block

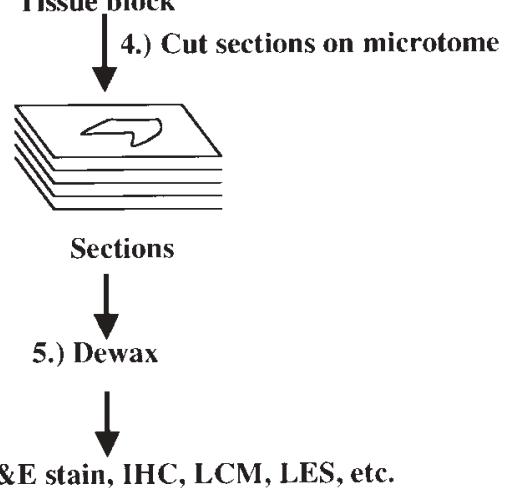

Figure 1. Steps of tissue handling for frozen and fixation and embedding. There are many more steps for tissue fixation and embedding, which can be impacted for preservation of DNA, RNA, and proteins than with freezing. Each method has advantages and disadvantages and prior to any study, an investigator needs to determine which method is appropriate based on the study to be performed and the tissue type.

\section{Clinical Aspects}

Pathologic examination of tissue sections involves patient care; therefore, it is essential that an accurate diagnosis be rendered. Traditionally, biopsy specimens and tissue from surgical resection are fixed in 10\% normal buffered formalin and embedded in paraffin. Tissue sections are then cut onto glass slides, which are hematoxylin and eosinstained. Since the histopathologic criteria for diagnosis of a variety of diseases in tissue is based on formalin fixation, it has become the gold standard for diagnostic histopathology.

Tissue is typically frozen either for an intraoperative consultation, or for molecular analysis. For intraoperative consultation, tissue sections are cut onto glass slides, which are then hematoxylin and eosin-stained. For frozen section diagnosis, the histology is usually adequate to identify the presence of a particular lesion; however, subtle histologic details may not be apparent. Therefore, the final diagnosis is typically rendered on other portions of the specimen which has been formalin-fixed. At present, molecular analysis is most commonly performed on "extra tissue" from the lesion, which is not required for diagnosis and staging. This is typically snap-frozen at the time of surgery and then used for a variety of molecular analyses.

\section{Sample Acquisition and Initial Tissue Handling}

If molecular profiling is a consideration for a specimen, then it is essential that careful planning and close coordination between clinicians, pathologists, and researchers take place prior to the procedure. This is to assure that tissue will be handled expeditiously in order to maximally preserve DNA, RNA, and proteins. After removal of tissue from the body, initial handling entails transportation from the operating room to the pathology department, inking surgical margins, and cutting the tissue into sufficiently small sections. During this period, degradation of biomolecules can occur, particularly proteins and RNA. Thus, there are essentially three major considerations of initial tissue handling to minimize degradation of biomolecules, including temperature, time of handling, and specimen size. To decrease the rate of biomolecular degradation, the tissue should be placed immediately on ice. All the steps of tissue preparation prior to fixation or snap-freezing including surgical margin inking and sectioning should proceed as quickly as possible. Finally, the smaller the tissue pieces are grossly sectioned, the better the preservation of biomolecules. 

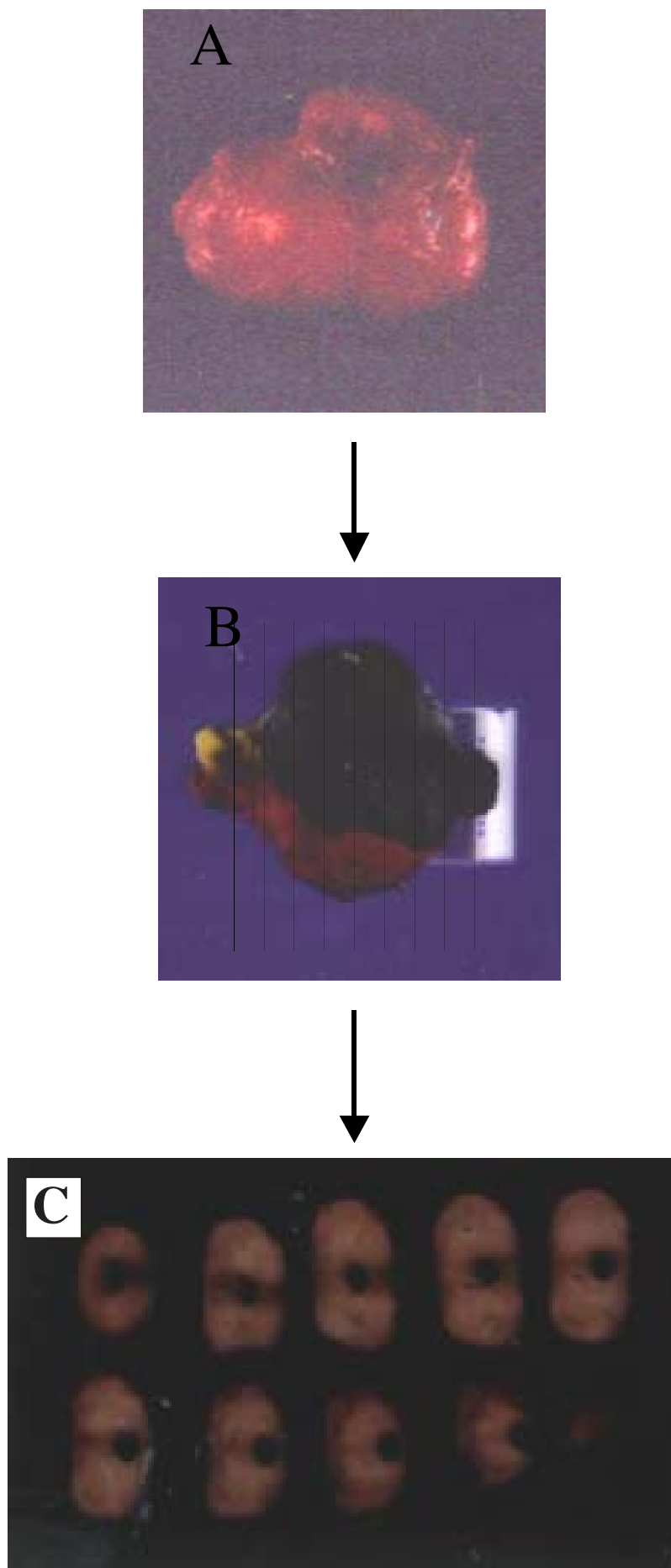

Figure 2. Steps of initial prostate handling. A. Fresh prostatectomy specimen is recovered from the operating room immediately after resection. B. Prostate after being inked with surgical ink or acrylic paint in order to delineate the surgical margin and to maintain the orientation. Lines, spaced every 3 to 5 $\mathrm{mm}$, show location of transverse sectioning from base to apex, which are perpendicular to the urethra. C. Sections of the prostate after being transverse sectioned with an extra large scalpel blade. These are then placed into cassettes, which are placed into fixative.
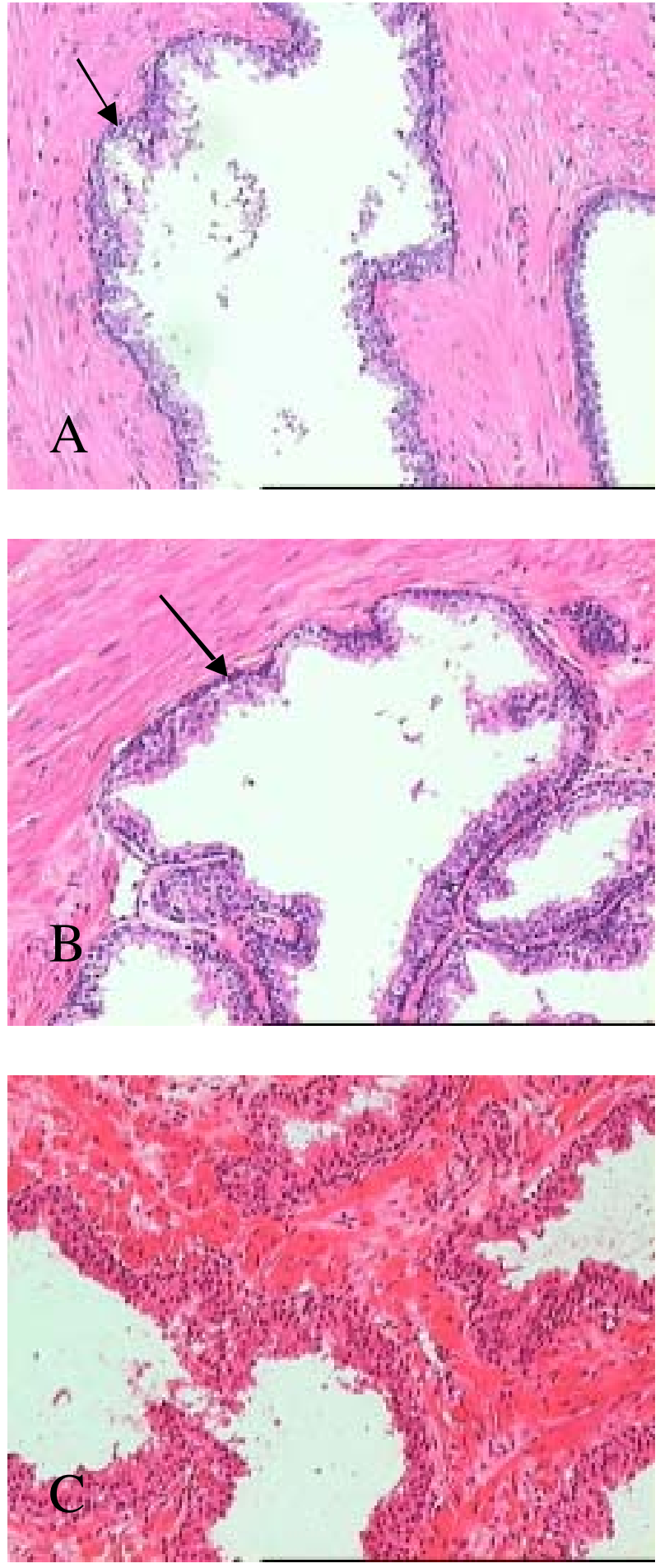

Figure 3. Comparison of fixatives on histology of prostate. Hematoxylin and eosin-stained sections of normal prostate show comparable architecture and cytology of formalin and $70 \%$ ethanol-fixed tissue, which are both superior to the frozen. Note the conspicuous basal cells (arrows) in the ethanol (A) and formalin-fixed specimens (B), which are inconspicuous in the frozen specimen $(C)$. Original magnification, X200. 


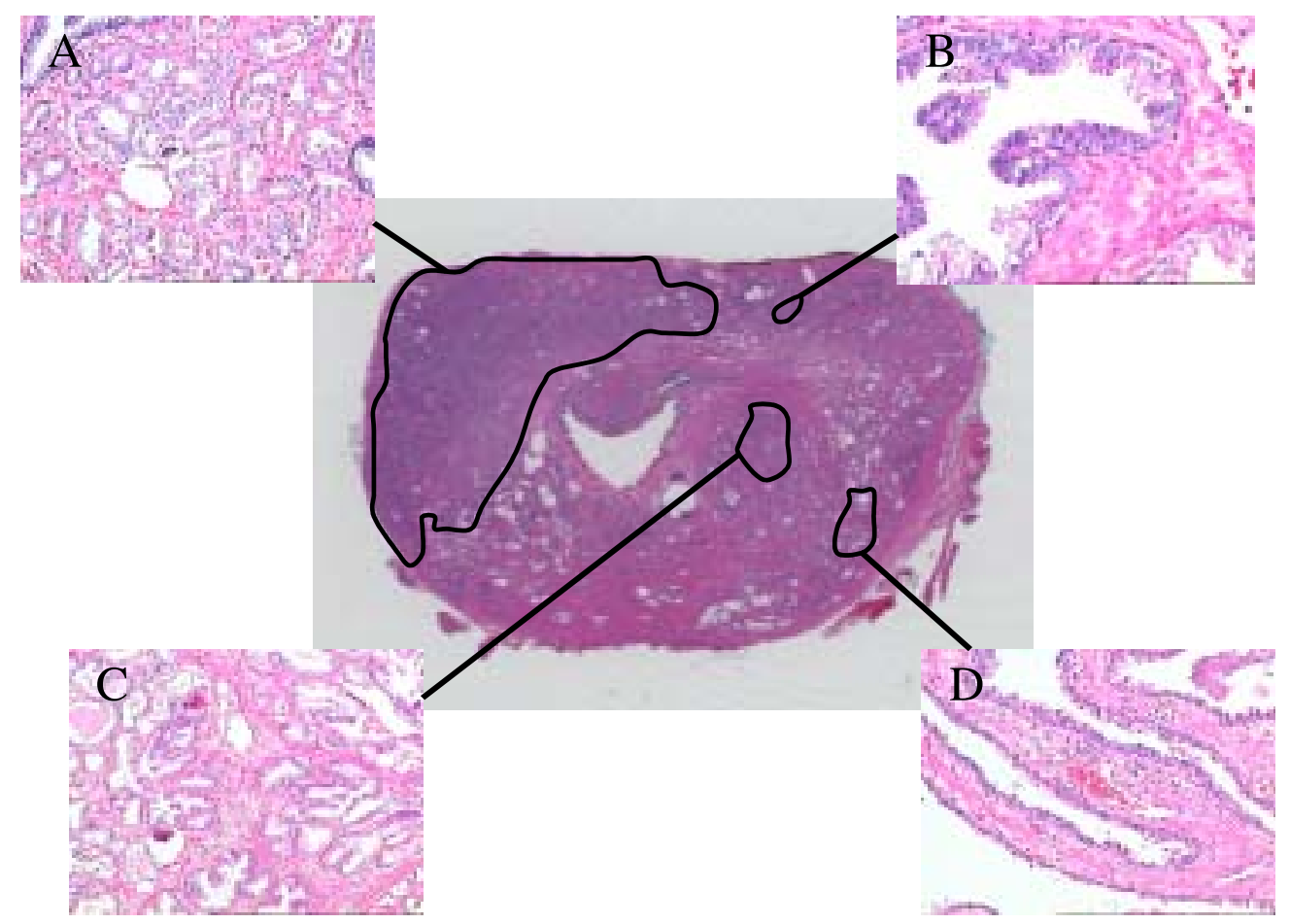

Figure 4. Annotation of whole-mount prostate tissue section. Scan of whole-mount prostate tissue section which has been $70 \%$ ethanol-fixed and paraffinembedded showing annotation of different areas showing different histologies. High-magnification images are representative histologies of the corresponding annotated areas. Whole-mounts with annotations form the basis for the 3-D model of prostate molecular profiling. Annotated areas show A. Carcinoma, B. Prostatic Intraepithelial Neoplasia (PIN), C. Hyperplasia, and D. Normal. Hematoxylin and eosin-stained, original magnification, X100.
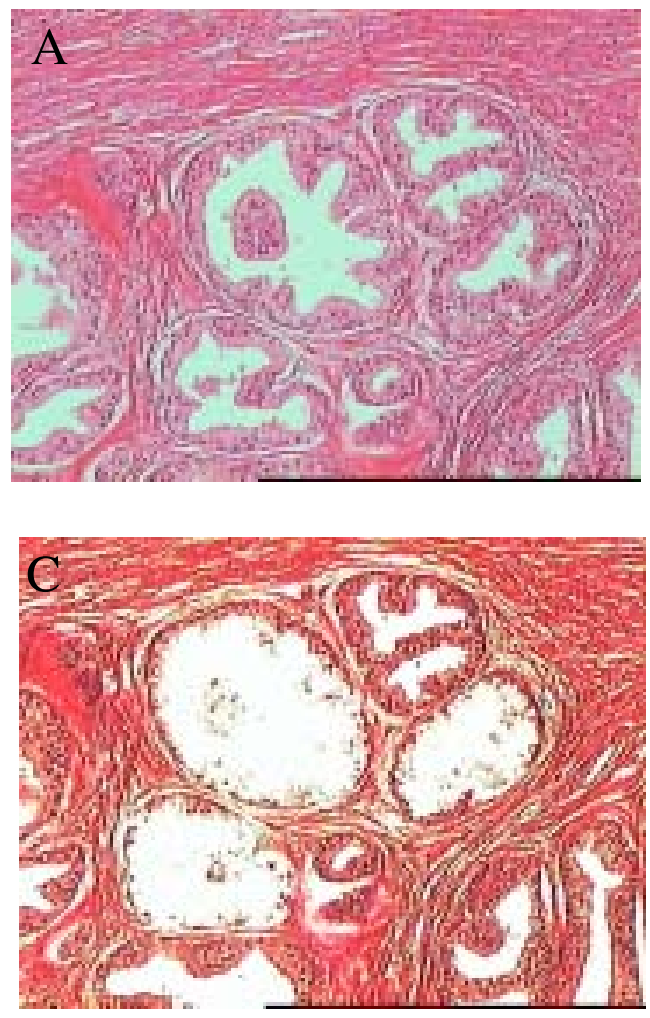

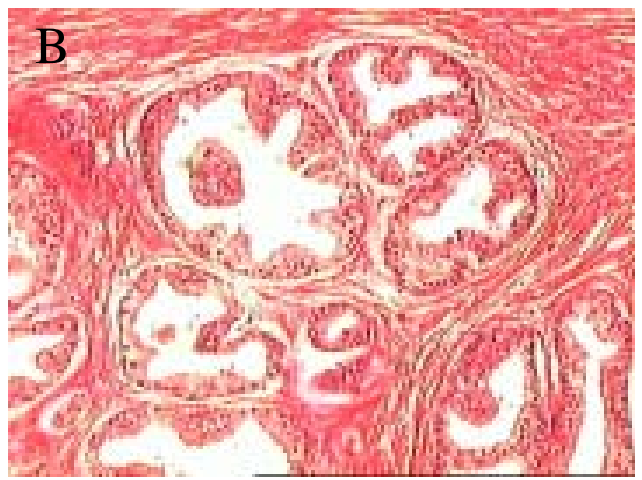

$\mathrm{D}$

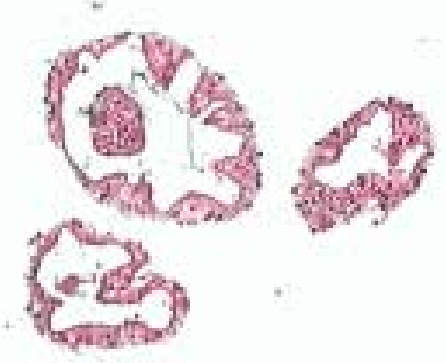

Figure 5. Laser Capture Microdissection (LCM) of prostate tissue Laser Capture Microdissection of ethanol-fixed and paraffin-embedded normal prostate epithelium. Prior to microdissection, the section was hematoxylin and eosin-stained. A. Roadmap, B. Pre-dissection, C. Post-dissection, and D. Cap images are taken to document the histology and the microdissected cells respectively. Note the high specificity of cells microdissected. 


\section{Tissue Fixation}

There are many different chemicals available for fixation and the choice depends on the purpose. The period of fixation will vary depending on the tissue type, the size of the specimen pieces, and the type of fixative. Fixation times usually vary from several hours to overnight. Tissues with higher fat content or larger size require longer fixation times. The two broad categories of fixatives include cross-linking and noncross-linking agents. Traditionally, the major consideration of fixation has been preservation of tissue architecture. To this end, the most commonly used fixative in pathology departments has been $10 \%$ buffered formalin, which has been used for diagnostic pathology for many decades. However, for any meaningful analysis to be obtained from biomolecules recovered from fixed tissue in the future, the use of alternative fixatives including noncross-linking and reversible cross-linking agents will likely play an important role.

\section{Tissue Embedding}

The purpose of embedding is to allow convenient storage of frozen or fixed tissue in a solid medium, allowing the tissue to be cut uniformly into very thin sections. For frozen samples, a piece of fresh tissue is placed in a cryomold which is then filled with OCT then frozen on dry ice or liquid nitrogen to form a block. The block is then stored at $-80^{\circ} \mathrm{C}$ or $-120^{\circ} \mathrm{C}$. For fixed tissue, after fixation the specimen is typically processed through multiple steps of dehydration in increasing concentrations of ethanol, and a final step in xylenes. This is followed by infiltration of the tissue with an embedding medium, usually a wax. After infiltration, the tissue is then placed in a mold and is embedded with the same medium to form a block. The block can then be stored at room temperature. Characteristics of the medium include the requirement that it be inert, be able to repel moisture, be able to readily penetrate tissue, cut a tissue section of uniform thickness, and maintain its integrity at room temperature. Various types of waxes fulfill these conditions including the widely-used embedding medium, paraffin wax. After the formation of blocks, tissue sections are cut in a cryostat or on a microtome from frozen or waxembedded blocks, respectively. Sections are typically cut at 5 to $10 \mu \mathrm{m}$ thickness onto glass slides.

\section{Evaluation of New Methods for Handling Clinical Tissue Specimens: Prostate Cancer as an Example of Tissue Handling for Molecular Analysis}

\section{New Methods of Fixation/Embedding}

Diverse methods of tissue fixation and embedding have been evaluated not only to produce excellent histology, but also to promote the elucidation of the gene and proteins expression profiles. Several methods utilizing alcoholbased fixation have shown promising results (Goldsworthy et al., 1999; Gillespie et al., 2000; Shibutami et al., 2000).

The development of an optimized protocol to fix and embed tissue that will not only preserve biomolecules, but also will retain excellent histology as seen in formalin fixation and paraffin embedding is an active area of investigation in our laboratory. Early work in our laboratory compared the recovery of RNA in murine tissue for a variety of alcohol-based and cross-linking fixatives. It was determined that the alcohol-based fixatives showed better recovery of RNA than the cross-linking fixatives (data unpublished). Subsequent work involving pathologists from Johns Hopkins University and National Institutes of Health in a blinded study compared the histology of small pieces of prostate tissue derived from prostatectomy specimens for the same fixatives (Gillespie et al., 2002). Besides giving excellent histology, seventy percent ethanol was selected for future studies over other fixatives since it gave very good recovery of RNA and is relatively inexpensive and non-toxic.

\section{Non Formalin Tissue Fixation}

Since the work described above, over 50 prostatectomy specimens have been processed as whole-mounts. In the operating room, immediately after the prostates are resected, they are placed immediately on ice. The prostates are then transported to the pathology department where the surgical margins are inked. Each prostate is then transverse sectioned into tissue sections, which are 3 to 5 $\mathrm{mm}$ thick and are orientated from the apex to the base of the gland (Figure 2). The sections are then fixed in $70 \%$ ethanol at $4^{\circ} \mathrm{C}$ and embedded in paraffin to form tissue blocks. From each of the blocks, a tissue section is cut which is then hematoxylin and eosin-stained. The entire prostate is then examined by a pathologist with the subsequent generation of a surgical pathology report.

\section{Comparison of Histology and Recovery of DNA, RNA,} and Proteins

In a small subset of these cases, besides fixation in $70 \%$ ethanol and paraffin-embedding, tissue sections were also snap-frozen, ethanol-fixed and polyester wax-embedded, and formalin-fixed and paraffin-embedded in order to do a more thorough comparison of the histopathology and recovery of DNA, RNA, and proteins (Gillespie, et al., 2002). The formalin and $70 \%$ ethanol-fixed samples show comparable histology and both are superior to the frozen sample (Figure 3). Normal, hyperplastic epithelium, intraepithelial neoplasia (PIN), and adenocarcinoma are readily distinguished from each other (Figure 4). Using PCR analysis, we observed that recovery of DNA is comparable for frozen and the ethanol fixed tissue, which are superior to the formalin-fixed tissue. Using total RNA analysis on denaturing gel and actin-specific RT-PCR, recovery of RNA is best from snap-frozen tissue, which is followed by ethanol-fixed tissue, and the least from formalin-fixed tissue. For ethanol-fixed tissue, RNA recovery can be improved by pre-incubation of the tissue lysates for 20 minutes at $60^{\circ} \mathrm{C}$ prior to RNA extraction. Using 1-D PAGE, recovery of total protein is comparable for frozen and the ethanol-fixed preparations which are both superior to formalin fixation. Recovery of protein from the formalinfixed sample is improved by pre-incubation of the tissue lysate at $80^{\circ} \mathrm{C}$ prior to protein extraction. Also, ethanolfixed tissue can be applied to a recently developed technique, Layered Expression Scanning (LES) (Englert et al., 2000) in which the entire protein content has been 
passed through 10 membrane layers. After staining with Coomassie blue, all layers also show retention of the anatomic structures seen within the original tissue section. This strategy for evaluating clinical tissue samples has shown that ethanol fixation and paraffin embedding allows for histology similar to formalin-fixation with much improved preservation of biomolecules over formalin-fixation.

\section{Tissue Microdissection-Based Approach to Molecular Profiling}

One of the technical challenges related to expression profiling of clinical samples is the difficulty of procuring specific cells from tissues that containing multiple cell populations. Normal and pathological tissue contains a highly complex three-dimensional structure typically comprised of a mixture of interacting cell populations, including normal, diseased, necrotic, and inflammatory cells, and the various cellular components of connective tissue. Consequently, if molecular analysis is performed on bulk tissue, the results will be representative not only of the cells of interest, but also of unwanted cells. Thus, in order to get an accurate representation of the molecular profile from diseased tissue, it is essential to procure the diseased cells from normal host cells.

Laser Capture Microdissection (LCM), which has been developed by our group (Emmert-Buck et al., 1996; Bonner et al., 1997), is a robust technique for rapid, precise and reproducible isolation of highly specific cell populations for molecular analysis. The system utilizes an infrared laser integrated into a specially designed microscope, which allows the selection of cells of interest based on microscopic visualization on tissue sections. The usual stain for visualization is hematoxylin and eosin-stained; however, the specificity of cells to be dissected can also be based on the immunophenotype (Fend et al., 1999; Kumar et al., 2000). An example of captured images of microdissection of prostate tissue is shown before, during and after the microdissection (Figure 5). This process does not affect the integrity proteins and nucleic acids and it can be used on formalin-fixed, ethanol-fixed, and frozen tissue sections.

Cells, which have been procured with LCM, have been applied to a variety of techniques for molecular analysis. Some of the commonly used procedures for DNA include mutational analysis, loss of heterozygosity (Brown et al., 1999) and comparative genomic hybridization (Jones et al., 2000). For RNA analysis, RT-PCR, cDNA library production, serial analysis of gene expression, and cDNA microarray analysis (Luo et al., 1999; Sgroi et al., 1999) are some of the common applications. For protein analysis, immunoblots, two dimensional gel electrophoresis (2-D PAGE) (Emmert-Buck et al., 2000; Ahram et al., 2002), and surface enhanced laser desorption ionization-time of flight (SELDI-TOF) (Wulfkuhle et al., 2001) are some of the techniques that have been applied. For details of the protocols, please see the protocols section and related information on the website (http://cgap-mf.nih.gov).

\section{High-Throughput Expression Methods}

Several high-throughput platforms have been developed for the performance of global measurements of transcriptomes and proteomes. These platforms can simultaneously analyze hundreds or thousands of expressed genes or proteins, which is extremely helpful in determining genes involved in diseases. Describe here work examining expression patterns of normal and diseased cell populations. This has been crucial to identify specific sets of genes that are dysregulated in disease, and establishing molecular profiles of normal and diseased cells.

\section{cDNA Microarray-Based Analysis}

The ability of nucleic acids to hybridize to each other with high degree of specificity and sensitivity, and the availability of $3^{\prime}$ clones representing the majority of human genes permit the performance of global expression measurements on biological samples (Drmanac et al., 1994; Schena et al., 1995; Drmanac et al., 1996). The potential of high-throughput expression microarrays to reveal fundamental biological information has been demonstrated (Schena et al., 1995; DeRisi et al., 1996; Perou et al., 1999; Alizadeh et al., 2000). The focus in our lab has been the determination of change for moderate and highly expressed genes during carcinogenesis. Groups of microdissected prostate epithelial cells and cancer cells were compared. The target was prepared by a RT-PCRbased method with incorporation of ${ }^{33} \mathrm{P}$ into total RNA, which was recovered from frozen tissue sections. Normal and tumor RNA were then hybridized to nylon array filter and the analysis revealed dysregulation of approximately 40 genes (Cole et al., 1999). Later, cDNA microarray analysis was performed on six high-grade prostate cancers and a reference sample pooled from normal prostate tissue. Hierarchical cluster analysis was performed for all genes which were either up- or down-regulated at least twofold on at least half of the arrays. The cancers were tightly clustered and 52 genes were consistently up- or downregulated in the majority of the cancers (Ahram et al., 2002). More recently, by examining gene expression profiles, we have identified 21 genes, which segregate moderate and high-grade prostate cancers (Best et al., unpublished). Most of the array data thus far has been obtained from frozen tissue. We have found that amplification of the transcriptome for cDNA microarray analysis is possible for $70 \%$ ethanol-fixed tissue; however, the effect of RNA hydrolysis during ethanol fixation and paraffin embedding on array analysis still needs to be assessed (Gillespie et al., 2002).

\section{Proteomic Analysis}

Functional interpretation of human diseases requires global analysis of gene expression complemented by protein expression. Studies measuring RNA levels only give information regarding gene expression. However, the final products of gene expression are proteins, which confer biological activity and cellular phenotype. Although studies at the mRNA level provide information of a large number of transcripts, this does not necessarily correlate with the 
level of protein expression (Anderson et al., 1997; Humphrey-Smith et al., 1997; Luo et al., 1999).

The main tool for protein separation is 2D-PAGE, which involves separation of proteins by isoelectric point in one dimension and molecular size in the second dimension. Each resultant "spot" on the two dimensional gel therefore constitutes a unique protein species. Each protein can be cut out of the gel, digested, and then identified by mass spectrometry. Protein analysis by 2-D PAGE will not only determine relative protein expression, but also can determine the presence of different isoforms and characterize post-translational modifications.

Proteins can be recovered from cells procured by LCM for 2D-PAGE and mass spectroscopy (Emmert-Buck et al., 1994; Banks et al., 1999; Emmert-Buck et al., 2000; Simone et al., 2000; Lawrie et al., 2001). Our laboratory analyzed proteomic profiles of patient-matched normal prostate epithelium and high-grade prostate cancer using tissue microdissection, 2D-PAGE and mass spectrometry. The expression level of more than seven hundred proteins was assessed and 41 tumor-specific changes were identified (Ahram et al., 2002). Approximately 400 proteins can be resolved by 2-D PAGE for ethanol-fixed tissue compared to approximately 1000 proteins from frozen tissue and less than 100 proteins from formalin-fixed tissue (data unpublished).

\section{Layered Expression Scanning}

The system of LES has been invented in our lab and being developed through a cooperative research and development agreement with 20/20 Genomics (http:// www.2020gene.com). It is a method to perform highthroughput analyses of nucleic acids and proteins. The principle entails eluting the protein and nucleic acid components from a tissue section through multiple ultrathin high-affinity, low-capacity membrane layers where the proteins and nucleic acids are bound. A specific protein or expressed gene can then be probed on each layer (Englert et al., 2000). By this method, the relationship between expression of various genes and proteins can be determined for all areas of a tissue section including diseased tissue as well as normal tissue. This method is especially useful to determine the anatomic relationship of gene and protein expression for areas of normal tissue, precancerous and cancerous tissue

\section{The 3-dimensional (3-D) Model of Prostate Molecular Profile}

Molecular profiling generates large data sets for analysis. How to best organize, evaluate and interpret the exponentially growing database of molecular profiling data obtained from tissue samples is an important goal of bioinformatics. Once this process is completed, the information can be utilized to obtain clinically relevant information such as a basis to design new strategies for diagnosis, prognosis, and therapy of prostate cancer.

To perform molecular profiling of prostate cancer progression, our group is taking a 3-D analytical approach to characterizing the entire prostate gland. In this approach, prostatectomy specimens are $70 \%$ ethanol-fixed and paraffin-embedded as whole-mounts with retention of orientation of the tissue in the blocks. Lesions and other anatomic areas are annotated on a representative hematoxylin and eosin-stained section from each tissue block. From these blocks, additional serial recut sections can be made for molecular analysis and profiling as well as hematoxylin and eosin-stained sections at intervals to determine anatomical changes within the prostate. The annotated areas from the stained section can undergo molecular analysis on the recut sections by cell procurement procedures (e. g. LCM) or the entire tissue section can be analyzed (e.g. LES, immunohistochemistry, in situ hybridization). The results of the molecular analysis can then be linked to the anatomic location in the prostate. In this way, not only is the molecular analysis performed on the plane of a tissue section in 2 dimensions, but by analyzing adjacent serial recut sections from the tissue blocks the molecular profiles of normal structures and lesions can be reconstructed in the third dimension to give a 3-D view of the prostate. The goals of the 3D model are to provide researchers with access to molecular information about prostate cancer as it relates to anatomic location within the prostate and to other lesions. Investigators are allowed to produce and query multiplex genomic and proteomic data and view this information in an appropriate context of complete spectrum of tumor progression: normal, dysplasia, and various grades of invasive tumors (Figure 4). In the 3D model, the molecular data and corresponding clinical information are being integrated into a single database as part of the Molecular Profiling Initiative (http://cgap-mf.nih.gov), (Cole et al., 1999).

\section{Conclusions and Future Directions}

With the rapidly expanding base of genetic information from the Human Genome Project, and the development of highthroughput technologies to obtain gene and protein expression profiles, it has become feasible to study the molecular basis of disease. The amount of molecular information that can be obtained from clinical tissue samples depends on how the samples are handled and processed. We have demonstrated that $70 \%$ ethanol fixation of prostate preserves histopathology and also allows for recovery of DNA, RNA, and proteins for subsequent molecular profiling studies We are continuing to investigate the types of molecular analyses that can be performed on ethanol-fixed samples, including the use of ethanol-fixed tissue for use on cDNA microarrays, as well as the stability of biomolecules and histology from $70 \%$ ethanol-fixed tissue over time.

Future efforts will include comparing many different fixatives for maintenance of excellent histology and preservation of biomolecules and examining the influence of the surgical procedure on molecular profiling. Reversible cross-linking agents in the fixative may preserve biomolecules in tissue for a long period of time by constricting the movement of biomolecules and inhibiting RNase and proteinase activity.

Ultimately, molecular profiling success depends on using a general strategy for evaluating clinical tissue specimens, with new fixation/embedding methods allowing 
investigators to perform high throughput molecular analysis on selected cell population on a sample. Continued improvement of tissue processing methodologies will be a critical step toward ultimately determining the molecular anatomy of normal and diseased human cell types.

\section{Acknowledgements}

The authors kindly thank Stephen Hewitt, M.D., Ph.D. for the images of the prostate used in Figure 2.

\section{References}

Ahram, M., Best, C.J.M., Flaig, M.J., Gillespie, J.W., Leiva, I.M., Chuaqui, R.F., Zhou, G., Shu, H., Duray, P.H., Linehan, W.M., Raffeld, M., Ornstein, D.K., Zhao, Y., Petricoin, E.F, and Emmert-Buck, M.R. 2002. Proteomic analysis of human prostate cancer. Mol. Carcinogen. 33: 9-15.

Alizadeh, A.A., Eisen, M.B., Eisen, M.B., Davis, R.E., Ma, C., Lossos, I.S., Rosenwald, A., Boldrick, J.C., Sabet, H., Tran, T., Yu, X., Powell, J.I., Yang, L., Marti, G.E., Moore, T., Hudson, J., Lu, L., Lewis, D.B., Tibshirani, R., Sherlock, G., Chan, W.C., Greiner, T.C., Weisenburger, D.D., Armitage, J.O., Warnke, R., Levy, R., Wilson, W., Grever, M.R., Byrd, J.C., Botstein, D., Brown, P.O., and Staudt, L.M. 2000. Distinct type of diffuse large B-cell lymphoma identified by gene expression profiling. Nature. 403: 503-511.

Anderson, L., and Seilhamer, J. 1997. A comparison of selected mRNA and protein abundances in human liver. Electrophoresis 18: 533-537.

Anderson, N., and Anderson, N.G. 1998. Proteome and proteomics: new technologies, new concepts and new words. Electrophoresis 19: 1853-1861.

Banks, R.E., Dunn, M.J., Forbes, M.A., Stanley, A., Pappin, D., Naven, T., Gough, M., Harnden, and Selby, P.J. 1999. The potential use of laser capture microdissection to selectively obtain distinct populations of cells for proteomics analysis-preliminary findings. Electrophoresis 20: 689-700.

Ben-Ezra, J., Johnson, D.A., Rossi, J., Cook, N., and Wu, A. 1991. Effect of fixation on the amplification of nucleic acids from paraffin-embedded material by the polymerase chain reaction. J. Histochem. Cytochem. 39: 351-354.

Bonner, R.F., Emmert-Buck, M.R., Cole, K.A., Pohida, T., Chuaqui, R.F., Goldstein, S.R.L., Zhuang, and Liotta, L.A. 1997. Laser capture microdissection: molecular analysis of tissue. Science. 278:1481-1483.

Brown, M.R., Chuaqui, R., Vocke, C.D., Berchuck, A., Middleton, L.P., Emmert-Buck, M.R., Kohn, E.C. 1999. Allelic loss on chromosome arm 8p: analysis of sporadic epithelial ovarian tumors. Gynecol. Oncol. 74 (1):98-102.

Celis, J., Rasmussen, H.H., Celis, P., Bodil, P., Lauridsen J.B., Ratz, G., Hein, B., Ostergaard, M., Orntoft, T., and Celis, J. 1999. Short-term culturing of low-grade superficial bladder transitional cell carcinoma leads to changes in the expression levels of several proteins involved in key cellular activities. Electrophoresis 20:355361 .
Cole, K.A., Krizman, D.B., and Emmert-Buck, M.R. 1999. The genetics of cancer-a 3D model. Nat. Genet. 21: 3841.

DeRisi, J.L., Penland, L., Brown, M.L., Meltzer, P.S., Ray, M., Chen, Y., Su, Y.A., and Trent, J.M. 1996. Use of a cDNA microarray to analysis gene expression pattern in human cancer. Nat. Genet. 14: 457-460.

Drmanac, S., and Drmanac, R. 1994. Processing of cDNA and genomic kilobase-size clones for massive screening, mapping and sequencing by hybridization. Biotechniques. 17: 328-329, 332-336.

Drmanac, S., Stavropoulus, N.A., Labat, I., Vonau, J., Hauser, B., Soares, M.B., and Drmanac, R. 1996. Generepresenting $\mathrm{C}$ DNA clusters defined by hybridization of 57,419 clones from infant brain libraries with short oligonucleotide probe. Genomics 37: 29-40.

Emmert-Buck, M.R., Bonner, R.F., Smith, P.D., Chuaqui, R.F., Goldstein, S.R., Zhuang, R.A., Weis, R.A., and Liotta, L.A. 1996. Laser capture microdissection. Science 274: 998-1001.

Emmert-Buck, M.R., Gillespie, J.W., Paweletz, C.P., Orstein D.K., Basrur, V., Apella, E., Wang, Q-H., Huang, J., Hu, N., Taylor P., and Petricoin, E.F. 2000. A strategic approach for proteomic analysis of human tumors. Mol. Carcinog. 27: 158-165.

Emmert-Buck, M.R., Roth, M.J., Zhuang, Z., Campo, E., Rozhin, J., Sloane, B.F., Liotta, L.A., and StetlerStevenson, W.G. 1994. Increased in gelatinase A (MMP2) and cathepsin $B$ activity in invasive tumor regions of human colon cancer samples. Am. J. Pathol. 145: 12851290.

Emmert-Buck, M.R., Strausberg, R.L., Krizman, D.B., Bonaldo, M.F., Bonner, R.F., Bonner, R.F., Bostwick, D.G., Brown, M.R., Buetow, K.H., Chuaqui, R.F., Cole, K.A., Duray, P.H., Englert, C.R., Gillespie, J.W., Greenhut, S., Grouse, L., Hillier, L.W., Katz, K.S., Klausner, R.D., Kuznetzov, V., Lash, A.E., Lennon, G., Linehan M.W., Liotta, L.A., Marra, M.A., Munson, P.J., Ornstein, D.K., Prabhu, V.V., Prange, C., Schuler, G.D., Bento Soares, M., Tolstoshev, C.M., Vocke, C.D., and Waterston, R.H. 2000. Molecular Profiling of Clinical Tissue Specimens: Feasibility and Applications. Am. J. Pathol. 156: 11091115.

Englert, C.R., Baibakov, G.V., and Emmert-Buck, M.R. 2000. Layered expression scanning: rapid molecular profiling of tumor samples. Cancer Res. 60: 1526-1530.

Fend, F., Emmert-Buck, M. R., Chuaqui, R., Cole, K., Lee, J., Liotta, L. A., and Raffeld, M. 1999. Immuno-LCM: Laser Capture Microdissection of Immunostained Frozen Sections for mRNA Analysis. Am. J. Pathol. 154: 61-66. Fend, F., Quintanilla-Martinez L., Kumar, S., Beaty, M.W., Blum, L., Sobara, L., Jaffe, E.F., and Raffeld, M. 1999. Composite low grade B-cell lymphomas with two immunophenotypically distinct cell population are true biclonal lymphomas: a molecular analysis using laser capture microdissection. Am. J. Pathol. 154: 1857-1866.

Gillespie, J.W., Best, C.J.M., Bichsel, V.E., Cole, K.A., Greenhut, S.F., Hewitt, S.M., Ahram, M., Gaithright, Y.B., Merino, M.J., Strausberg, R.L., Epstein, J.I., Hamilton, S.R., Gannot, G., Baibakova, G.V., Calvert, V.S., Flaig, M.J., Chuaqui, R.F., Herring, J.C., Pfeifer, J., Petricoin, 
E.F., Linehan, W.M., Duray, P.H., Bova, G.S., and Emmert-Buck, M.R. 2000. Evaluation of non-formalin tissue fixation for molecular profiling studies. Am. J. Pathol. 156: 1109-1115.

Goldsworthy, S.M., Stockton, P.S., Trempus, C.S., Foley, J.F., and Maronpot R.R. 1999. Effects of fixation on RNA extraction and amplification from laser capture microdissected tissue. Mol. Carcinog. 25: 86-91.

Humprey-Smith, I., Cordwell, S.J., and Blackstock, W.P. 1997. Proteome research: Complementarity and limitations with respect to the RNA and DNA worlds. Electrophoresis 18: 1217-1242.

Jones C, Foschini MP, Chaggar R, Lu YJ, Wells D, Shipley JM, Eusebi V, Lakhani SR. 2000. Comparative genomic hybridization analysis of myoepithelial carcinoma of the breast. Lab Invest. 80: 831-6.

Klimecki, W.T., Futscher, B.W., and Dalton, W.S. 1994. Effects of ethanol and paraformaldehyde on RNA yield and quality. Biotechniques 16: 1021-1023.

Kumar, S., Fend, F., Quintanilla-Martinez L., Kingma, D.W., Sorbara, L., Raffeld, M., Banks, P.M., and Jaffe, E.S. 2000. Epstein-Barr virus positive primary gastrointestinal Hodgking's disease: association with inflammatory bowel disease and immunosuppression. Am. J. Surg. Pathol. 24: 66-73.

Lawrie, L.C., Curran, S., McLeod, H.L., Fothergill, J.E., and Murray, G.I. 2001. Application of laser capture microdissection and proteomics in colon cancer. Mol. Pathol. 54: 253-8.

Lipshutz, R., Fodor, S.P.A., Gingeras, T.R., and Lockhart, D.J. 1999. High density synthetic oligonucleotide arrays. Nat. Genet. 21: 20-24.

Luo, L., Salunga, R.C., Guo, H., Bittner, A., Joy, K.C., Galindo, J.E., Xiao, H., Rogers, K.E., and Wan, M.R. 1999. Gene expression profile of laser-capture adjacent neuronal subtypes. Nature Med. 5: 117-122.
Ornstein, D.K., Gillespie, J.W., Paweletz, C.P., Duray, P.H., Herring, J., Vocke, C.D., Topalian, S.L., Bostwick, D.G., Linehan, W.M., Petricoin, E.F., and Emmert-Buck, M.R. 2000. Proteomic analysis of laser capture microdissected human prostate cancer and in vitro prostate cell lines. Electrophoresis 21: 2235-2242.

Perou, C.M., Jeffrey, S.S., van de Rijn, M., Eisen, M.B., Ross D.T., Pergamenschikov, A. Williams, C.F., Zhu, S.X., Lee, J.C. Lashkari, D., Shalon, D., Brown, P.O., and Botstein, D. 1999. Distinctive gene expression patterns in human mammary epithelial cells and breast cancers. Proc. Natl. Acad. Sci. 96: 921-9217.

Schena, M., Shalon, D., Davis, R.W., and Brown, P.O. 1995. Quantitative monitoring of gene expression patterns with a complementary DNA microarray. Science 270: 467-469. Sgroi, D.C., Tengs, S., Robinson, G., LeVangie, R., Hudson, J.R., and Elkahloun A.G. 1999. In vivo gene expression profile analysis of human breast cancer progression. Cancer Res. 59: 5656-5661.

Shibutani, M., Unemaya, C., Miyazaki, K., Teyoda, K., and Hirose, M. 2000. Methacam fixation: a novel tool for analysis of gene expressions in paraffin-embedded tissue specimens. Lab. Invest. 80: 199-208.

Simone, N.L., Remaley, A.T., Charboneau, L., Petricoin, E.F., Glickman, J.W., Emmert-Buck, M.R., Fleisher, T.A., and Liotta, L.A. 2000. Sensitive immunoassay of tissue cell proteins procured by laser capture microdissection. Am. J. Pathol. 156: 445-452.

Wulfkuhle, J.D., McLean, K.C., Paweletz, C.P., Sgroi, D.C., Trock, B.J., Steeg, P.S., Petricoin, E.F.3rd. 2001. New approaches to proteomic analysis of breast cancer. Proteomics. 1:1205-15.

Zhang, L., Zhou, W., Velculescu, V.E., Kern, S.E., Hruban, R.H., Hamilton, S.R., Vogelstein, B., and Kinzler, K.W. 1997. Gene expression profiles in normal and cancer cells. Science 276: 1268-1272. 


\section{Further Reading}

Caister Academic Press is a leading academic publisher of advanced texts in microbiology, molecular biology and medical research. Full details of all our publications at caister.com

- MALDI-TOF Mass Spectrometry in Microbiology Edited by: M Kostrzewa, S Schubert (2016) www.caister.com/malditof

- Aspergillus and Penicillium in the Post-genomic Era Edited by: RP Vries, IB Gelber, MR Andersen (2016) www.caister.com/aspergillus2

- The Bacteriocins: Current Knowledge and Future Prospects Edited by: RL Dorit, SM Roy, MA Riley (2016)

www.caister.com/bacteriocins

- Omics in Plant Disease Resistance Edited by: V Bhadauria (2016) www.caister.com/opd

- Acidophiles: Life in Extremely Acidic Environments Edited by: R Quatrini, DB Johnson (2016) www.caister.com/acidophiles

- Climate Change and Microbial Ecology: Current Research and Future Trend

Edited by: J Marxsen (2016)

www.caister.com/climate

- Biofilms in Bioremediation: Current Research and Emerging Technologies

Edited by: G Lear (2016)

www.caister.com/biorem

- Microalgae: Current Research and Applications Edited by: MN Tsaloglou (2016) www.caister.com/microalgae

- Gas Plasma Sterilization in Microbiology: Theory, Applications, Pitfalls and New Perspectives Edited by: H Shintani, A Sakudo (2016) www.caister.com/gasplasma

- Virus Evolution: Current Research and Future Directions Edited by: SC Weaver, M Denison, M Roossinck, et al. (2016) www.caister.com/virusevol

- Arboviruses: Molecular Biology, Evolution and Control Edited by: N Vasilakis, DJ Gubler (2016) www.caister.com/arbo

- Shigella: Molecular and Cellular Biology Edited by: WD Picking, WL Picking (2016) www.caister.com/shigella

-Aquatic Biofilms: Ecology, Water Quality and Wastewater Treatment

Edited by: AM Romaní, H Guasch, MD Balaguer (2016)

www.caister.com/aquaticbiofilms

- Alphaviruses: Current Biology

Edited by: S Mahalingam, L Herrero, B Herring (2016)

www.caister.com/alpha

- Thermophilic Microorganisms

Edited by: F Li (2015)

www.caister.com/thermophile
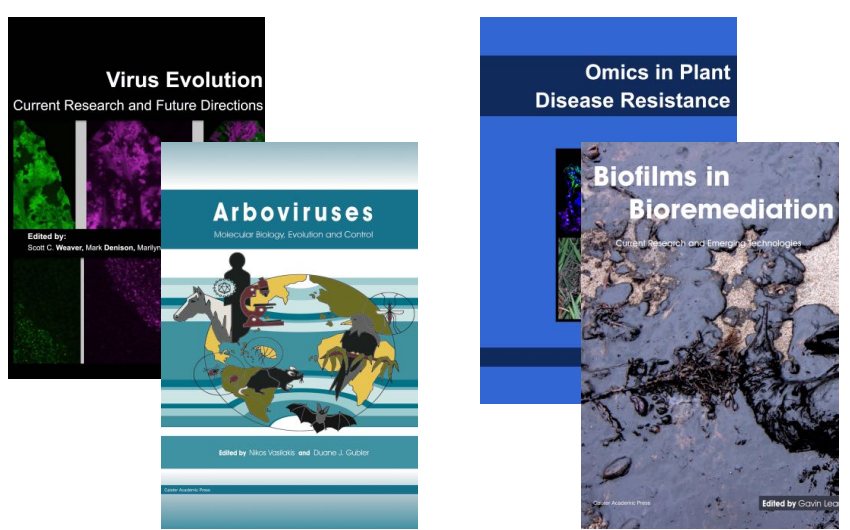
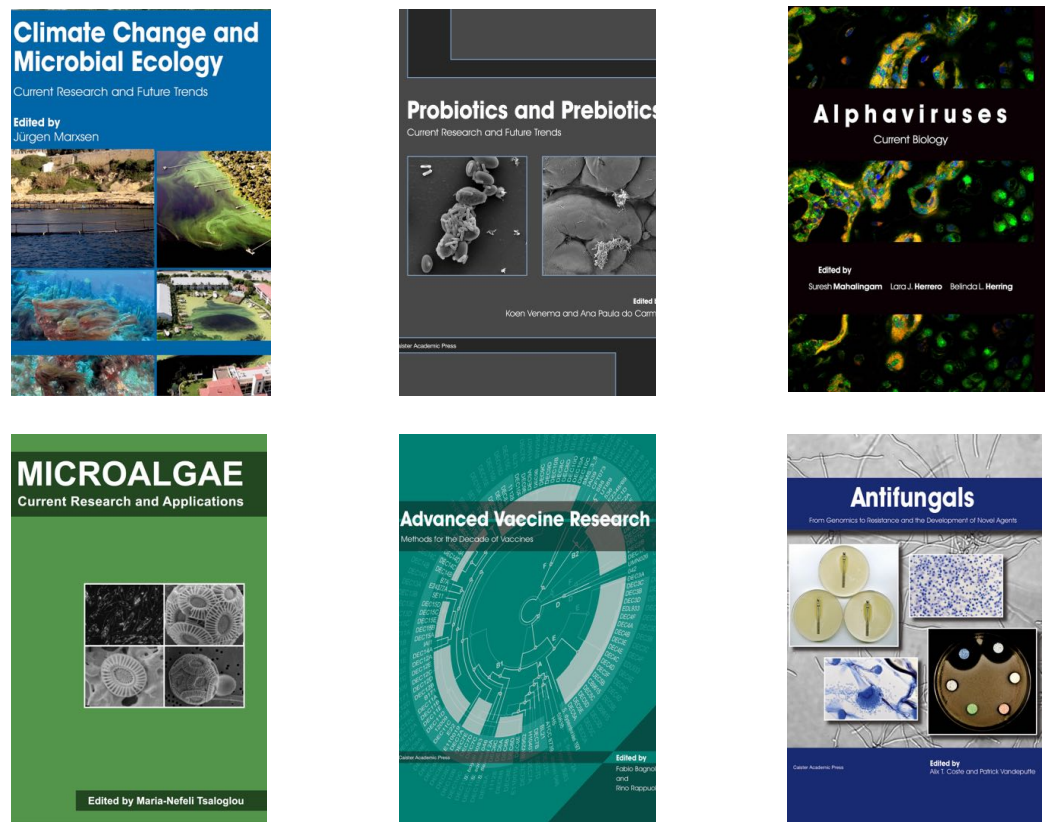

- Flow Cytometry in Microbiology: Technology and Applications Edited by: MG Wilkinson (2015) www.caister.com/flow

- Probiotics and Prebiotics: Current Research and Future Trends Edited by: K Venema, AP Carmo (2015) www.caister.com/probiotics

- Epigenetics: Current Research and Emerging Trends Edited by: BP Chadwick (2015) www.caister.com/epigenetics2015

- Corynebacterium glutamicum: From Systems Biology to Biotechnological Applications

Edited by: A Burkovski (2015)

www.caister.com/cory2

- Advanced Vaccine Research Methods for the Decade of Vaccines

Edited by: F Bagnoli, R Rappuoli (2015)

www.caister.com/vaccines

- Antifungals: From Genomics to Resistance and the Development of Novel Agents

Edited by: AT Coste, P Vandeputte (2015)

www.caister.com/antifungals

- Bacteria-Plant Interactions: Advanced Research and Future Trends Edited by: J Murillo, BA Vinatzer, RW Jackson, et al. (2015) www.caister.com/bacteria-plant

\section{- Aeromonas}

Edited by: J Graf (2015)

www.caister.com/aeromonas

- Antibiotics: Current Innovations and Future Trends

Edited by: S Sánchez, AL Demain (2015)

www.caister.com/antibiotics

- Leishmania: Current Biology and Contro Edited by: S Adak, R Datta (2015) www.caister.com/leish2

- Acanthamoeba: Biology and Pathogenesis (2nd edition) Author: NA Khan (2015)

www.caister.com/acanthamoeba2

- Microarrays: Current Technology, Innovations and Applications Edited by: Z He (2014)

www.caister.com/microarrays2

- Metagenomics of the Microbial Nitrogen Cycle: Theory, Methods and Applications

Edited by: D Marco (2014)

www.caister.com/n2 